University of Nebraska - Lincoln

DigitalCommons@University of Nebraska - Lincoln

\title{
Classifying the Hydrologic Function of Prairie Potholes with Remote Sensing and GIS
}

\author{
Jennifer Rover \\ United States Geological Survey, jrover@usgs.gov \\ Chris K. Wright \\ South Dakota State University \\ Ned H. Euliss Jr. \\ U.S. Geological Survey, ceuliss@usgs.gov \\ David M. Mushet \\ U.S. Geological Survey, dmushet@usgs.gov \\ Bruce K. Wylie \\ United States Geological Survey, wylie@usgs.gov
}

Follow this and additional works at: https://digitalcommons.unl.edu/usgsnpwrc

Rover, Jennifer; Wright, Chris K.; Euliss, Ned H. Jr.; Mushet, David M.; and Wylie, Bruce K., "Classifying the Hydrologic Function of Prairie Potholes with Remote Sensing and GIS" (2011). USGS Northern Prairie Wildlife Research Center. 281.

https://digitalcommons.unl.edu/usgsnpwrc/281

This Article is brought to you for free and open access by the US Geological Survey at DigitalCommons@University of Nebraska - Lincoln. It has been accepted for inclusion in USGS Northern Prairie Wildlife Research Center by an authorized administrator of DigitalCommons@University of Nebraska - Lincoln. 


\title{
Classifying the Hydrologic Function of Prairie Potholes with Remote Sensing and GIS
}

\author{
Jennifer Rover • Chris K. Wright • Ned H. Euliss, Jr. • \\ David M. Mushet • Bruce K. Wylie
}

Received: 27 May 2010 / Accepted: 3 January 2011 / Published online: 22 February 2011

(C) US Government 2011

\begin{abstract}
A sequence of Landsat TM/ETM+ scenes capturing the substantial surface water variations exhibited by prairie pothole wetlands over a drought to deluge period were analyzed in an attempt to determine the general hydrologic function of individual wetlands (recharge, flowthrough, and discharge). Multipixel objects (water bodies) were clustered according to their temporal changes in water extents. We found that wetlands receiving groundwater discharge responded differently over the time period than wetlands that did not. Also, wetlands located within topographically closed discharge basins could be distinguished from discharge basins with overland outlets. Field verification data showed that discharge wetlands with closed basins were most distinct and identifiable with reasonable accuracies (user's accuracy $=97 \%$, producer's accuracy $=71 \%$ ). The classification of other hydrologic function types had lower accuracies reducing the overall accuracy for the four hydrologic function classes to $51 \%$. A simplified classification approach identifying only two hydrologic function classes was $82 \%$. Although this technique has limited success for detecting small wetlands,
\end{abstract}

J. Rover $(\triangle) \cdot$ B. K. Wylie

United States Geological Survey,

Earth Resources Observation and Science Center,

Mundt Federal Building, 47914 252nd St,

Sioux Falls, SD 57198, USA

e-mail: jrover@usgs.gov

C. K. Wright

Geographic Information Science Center of Excellence,

South Dakota State University,

Brookings, SD 57007, USA

N. H. Euliss, Jr. • D. M. Mushet

United States Geologic Survey,

Northern Prairie Wildlife Research Center,

Jamestown, ND 58401, USA
Landsat-derived multipixel-object clustering can reliably differentiate wetlands receiving groundwater discharge and provides a new approach to quantify wetland dynamics in landscape scale investigations and models.

Keywords Landsat · Cluster analysis · Wetland classification $\cdot$ Object-oriented image analysis

\section{Introduction}

The use of optical and microwave satellite data is common in studies of wetland vegetation and inundation across a range of spatial and temporal scales (Ozesmi and Bauer 2002; Melack 2004; Mertes et al. 2004; Henderson and Lewis 2008). However, the timing of data acquisition, temporal variability of wetland water levels, and limited spatial resolution can complicate the use of satellite data for wetland classification (Ozesmi and Bauer 2002). Given these limitations, wetlands are commonly classified and mapped with high resolution aerial photography, e.g. the National Wetlands Inventory (USFWS 2008), albeit at a higher cost and, consequently, with limited temporal repeatability.

A number of studies have taken advantage of the moderate resolution, 16-day return cycle, and long acquisition history available from the Landsat program (http://landsat.gsfc.nasa.gov) to study surface water (Work and Gilmer 1976; Leahy et al. 2005; Baker et al. 2007; Jones et al. 2009). In the Prairie Pothole Region (PPR) of central North America, several remote sensing studies used Landsat data acquired during the 1980 s to 2000 s to study water dynamics (Sethre et al. 2005; Beeri and Phillips 2007; Zhang et al. 2009a; b). These studies described open water detection techniques, identified open water variations 
and distributions, and quantified seasonal and annual surface water variability, but did not examine if the dynamics of visible surface water in a prairie pothole reflected the underlying hydrologic function of that particular wetland, i.e. its relationship to ground water.

In the PPR, groundwater connectivity influences wetland hydroperiod and the composition of wetland plant and animal communities (Kantrud et al. 1989; Cowardin and Golet 1995; LaBaugh et al. 1998; Euliss et al. 2004; Johnson et al. 2004; van der Valk 2005). In addition, the type of basin a wetland is located in can affect wetland hydroperiods. Basins can be open or closed where open basins contain a spill point allowing for overland outflow and closed basins do not.

Generally, prairie potholes that are located in areas where ground water is discharged (hereafter referred to as discharge wetlands) tend to have high solute concentrations (Swanson et al. 1988; LaBaugh et al. 1996; LaBaugh et al. 1998) and consistently contain surface water, even during moderately dry periods. By contrast, wetlands contributing to groundwater recharge but not receiving groundwater discharge (hereafter referred to as recharge wetlands) usually depend entirely on water inputs from precipitation and subsequent overland flow. These wetlands have low solute concentrations and typically contain surface water on a temporary basis, limited to early spring or after periods of heavy precipitation. Wetlands that receive groundwater discharge in part of their basin while also contributing to groundwater recharge in other parts are referred to as flowthrough wetlands (LaBaugh 1989). Flow-through wetlands tend to have intermediate solute concentrations.

This paper describes the utility of a new method for classifying changes in surface water extent in order to estimate the hydrologic function of individual wetlands across a large area. The method uses terrain analysis, a time series of seven Landsat TM and ETM + scenes acquired during a multiyear drought-to-deluge cycle, and a specialized clustering algorithm for large datasets. The ability to classify wetlands by their dynamics would facilitate the prediction and the modeling of ecosystem services associated with different wetland hydrologic functional classes across entire wetland regions, an objective of the U.S. Geological Survey (USGS) Integrated Landscape Monitoring Initiative (Koshel and McAllister 2008).

\section{Methods}

Study Area and Landsat Data

The study area was located in the Missouri Coteau portion (approximately $5,400 \mathrm{~km}^{2}$ ) of Landsat path $31 /$ row 27 in east-central North Dakota (Fig. 1). The Missouri Coteau was formed by glacial deposition and is approximately $400 \mathrm{~m}$ higher in elevation than the Drift Plain located to the east. Locally, topography varies by approximately $30 \mathrm{~m}$ (Winter and Rosenberry 1998). Non-irrigated agriculture is the primarily land use and livestock grazing is common in areas unsuited for cultivation (USGS 2001). The average annual precipitation (1951 June to 2005 April) was approximately $444 \mathrm{~mm}$ and fell during the summer months (High Plains Regional Climate Center 2005), but annual precipitation is variable with multiyear cycles of below- and above-normal precipitation (Winter and Rosenberry 1998). The region experienced a dry period from the late 1980s through 1992, followed by the wettest period in a century (Winter and Rosenberry 1998; Rosenberry 2003), producing ideal conditions for analyzing changes in surface water with Landsat data.

\section{Surface Water Remote Sensing}

We generated binary water/nonwater maps using Landsat imagery from seven dates (Table 1) across a drought-todeluge cycle. Water bodies were identified at each image date using a supervised classification method developed in See5 v2.03 (http://www.rulequest.com). The classification model was trained by manually locating water and nonwater pixels $(1,000$ pixels per image). The radiance band values except the thermal and panchromatic bands were

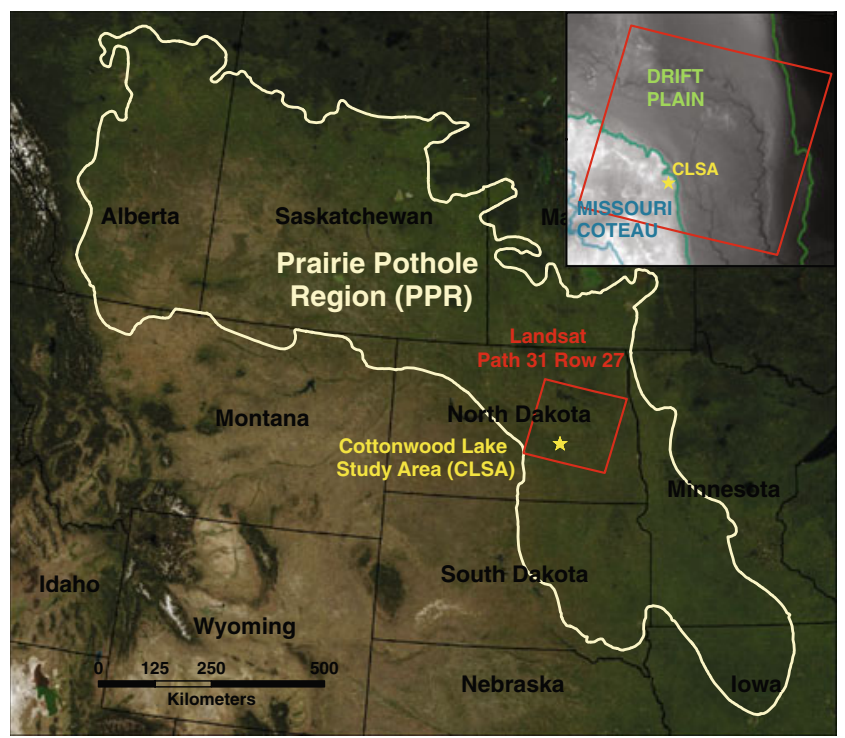

Fig. 1 Location of Landsat (path 31/row 27) scene (red square) within the Prairie Pothole Region (light yellow outline) and ESRI satellite data in the background (http://services.arcgisonline.com). The subset illustrates elevation produced from the 30-m DEM, the Missouri Coteau (blue outline) where higher values (white) with more relief are common, than the flatter and lower (black) terrain of the Drift Plain. Classified wetlands were located within the Missouri Coteau portion of the Landsat scene (Missouri Coteau boundary, courtesy Ducks Unlimited) 
Table 1 Landsat sensor and acquisition date

\begin{tabular}{lll}
\hline Sensor & Year & Day \\
\hline TM & 1989 & 21 May \\
TM & 1991 & 12 Jun \\
TM & 1997 & $14 \mathrm{Jul}$ \\
ETM+ & 2001 & $1 \mathrm{Jul}$ \\
TM & 2003 & $12 \mathrm{May}$ \\
ETM+SLC-off & 2004 & 9 Jul \\
TM & 2005 & 18 Jun \\
\hline
\end{tabular}

extracted at each training pixel for decision tree development. After each decision tree was applied to its respective Landsat scene, we visually inspected each classified image and, if needed, added additional training points from areas where either the water or nonwater pixels were incorrectly predicted. The final accuracies of the seven decision tree models averaged 99\%. After classifying the water bodies, each image was converted to a polygon vector format with smoothing to remove pixel corner effects in ArcMap (ESRI 2006). The vectors were merged to create a maximum water extent for each water body.

\section{Terrain Analysis}

After producing surface water maps, we found that some wetlands located in close proximity, but sometimes with different hydrologic functions, coalesced under high water conditions to form single water bodies. This made it necessary to develop a method to separate converging polygons. Using watershed delineation techniques and an unfilled 30-m DEM (USGS 2006) we identified individual wetland delineation units. Slopes were calculated in degrees based on the rate of elevation change between each pixel and the neighboring pixel with the highest elevation. The slope data, rather than elevation, were then used to generate flow direction and identify pixels with no outflow. These slope-based sinks were then used as pour points in a watershed analysis to determine the contributing area of each sink, the area we refer to in subsequent analysis as the wetland delineation unit. When compared to classic elevation raster processing methods (e.g., Jenson and Domingue 1988; Jenson 1991), this slope-based method increased the number depressions identifiable in the DEM.

\section{Cluster Analysis}

Our cluster analysis classified wetland delineation units as one of four general types of hydrologic function: recharge, flowthrough, open discharge, and closed discharge. Within each delineation unit, we calculated variation in surface water extent in two ways: (1) as a percentage of the maximum water extent; (2) as a percentage of the wetland delineation unit (Fig. 2). We used two calculations for each wetland given that the maximum extent of some wetlands occupied nearly the entire wetland delineation unit, while others only occupied a fraction of their respective delineation units (Fig. 2). In turn, the temporal signature of each wetland was represented by a 14-value vector ( 7 dates $\times 2$ bases).

Where water was detected at only one date, wetlands were automatically assigned to the recharge class. The remaining wetland delineation units $(n=26,774)$ were classified using an unsupervised approach, CLARA (Clustering LARge Applications) algorithm (Kaufman and Rousseeuw 2005), implemented in S-Plus (Insightful Corp., version 6.1.2, 2002). In this case, CLARA grouped surface water temporal patterns into four classes such that distances between individual 14-dimensional vectors and their respective class centers (also called medoids) were minimized overall (Kaufman and Rousseeuw 2005). We then compared these cluster centers to surface water variability we detected in 14 wetlands with known hydrologic functions from the extensively-studied Cottonwood Lake Study Area (CLSA; Fig. 3; Swanson et al. 2003). Using the patterns from these known types as a guide, we assigned hydrologic

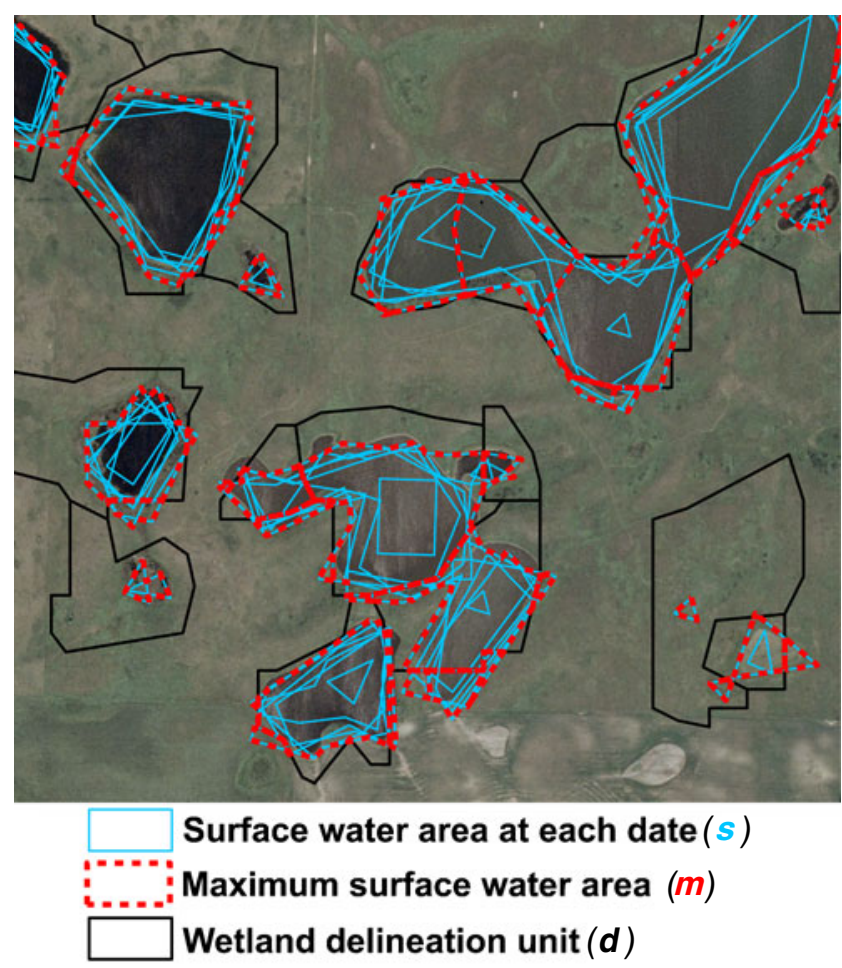

1. Percent of maximum water extent $=\operatorname{s} / m(100)$

\section{Percent of wetland delineation unit $=s / d(100)$}

Fig. 2 An example of surface water polygons extracted from each scene (blue), maximum surface water area (red), and wetland delineation units (black) overlying a DOQQ 
Percent of Maximum Water Extent
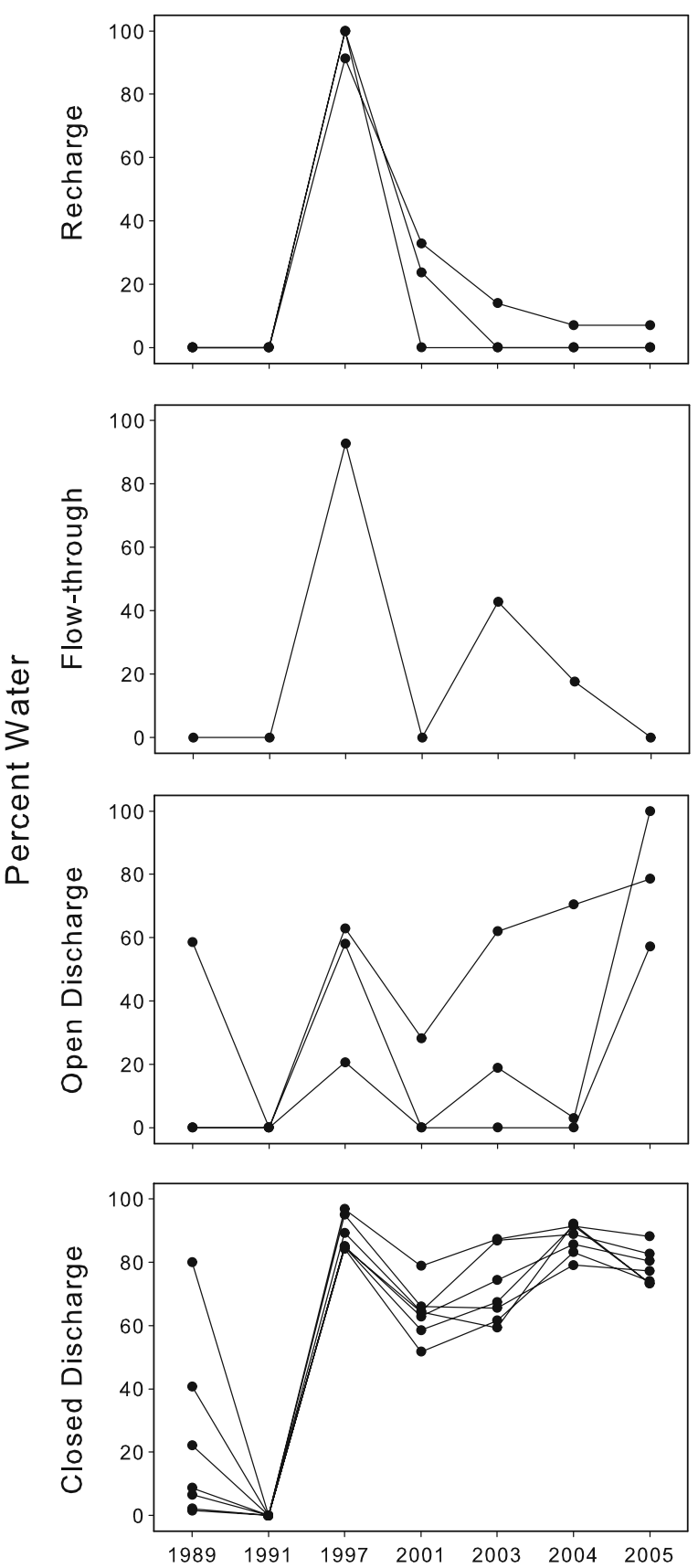

Percent of Wetland Delineation Unit
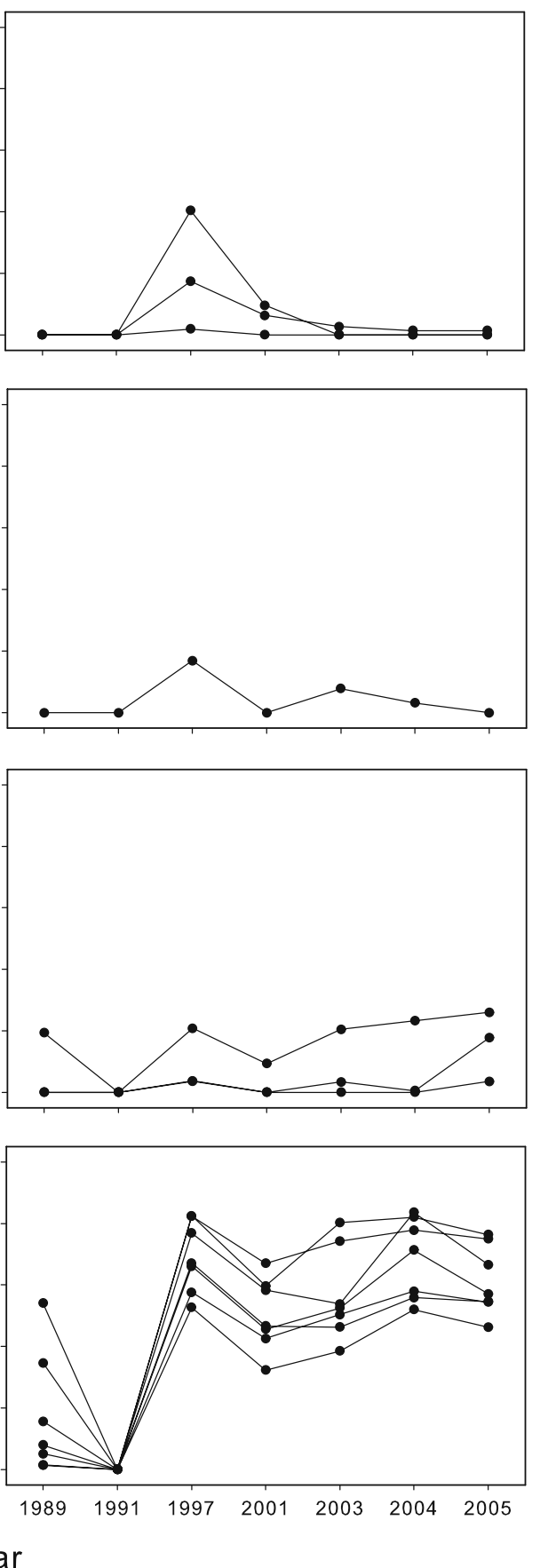

Fig. 3 Surface water patterns for 14 individual wetlands located at CLSA calculated with the percent of maximum water extent and percent of wetland delineation unit methods for known recharge, flow-through, open discharge, and closed discharge wetlands

function labels to the characteristic patterns (cluster centers) generated by our unsupervised classification.

After labels were assigned to each cluster, a subsequent field investigation (see Field Validation section for methods) of 28 wetlands located in close proximity of CLSA showed that our predictions tended to confuse flowthrough and open discharge basins. Thus, we modified our clustering scheme (Fig. 4) by reclassifying wetlands assigned to the flow-through and open discharge vectors by performing an additional unsupervised classification to split these confused classes, a technique known as "cluster busting." This clustering scheme based on the 14 CLSA wetlands and 28 additional wetlands identified hydrologic functions with an overall accuracy of $86 \%$ (Table 2). 
(a)

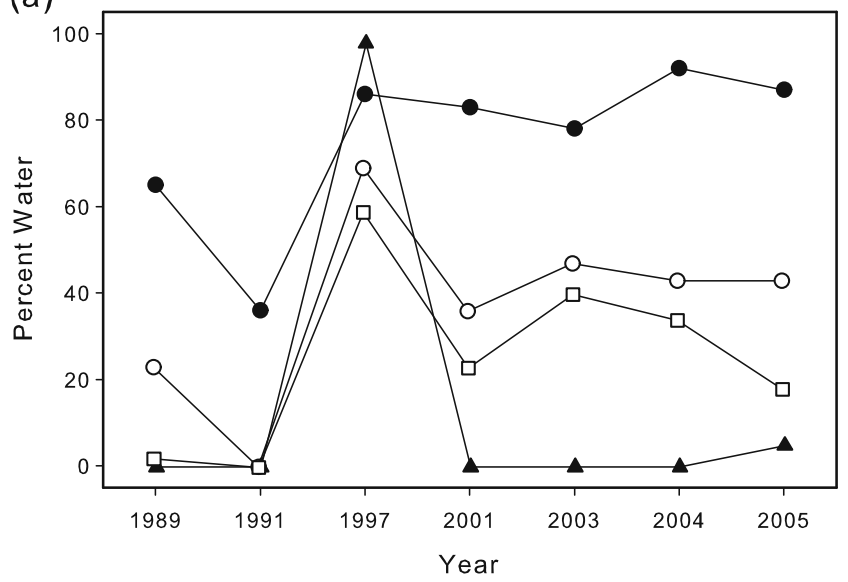

(b)

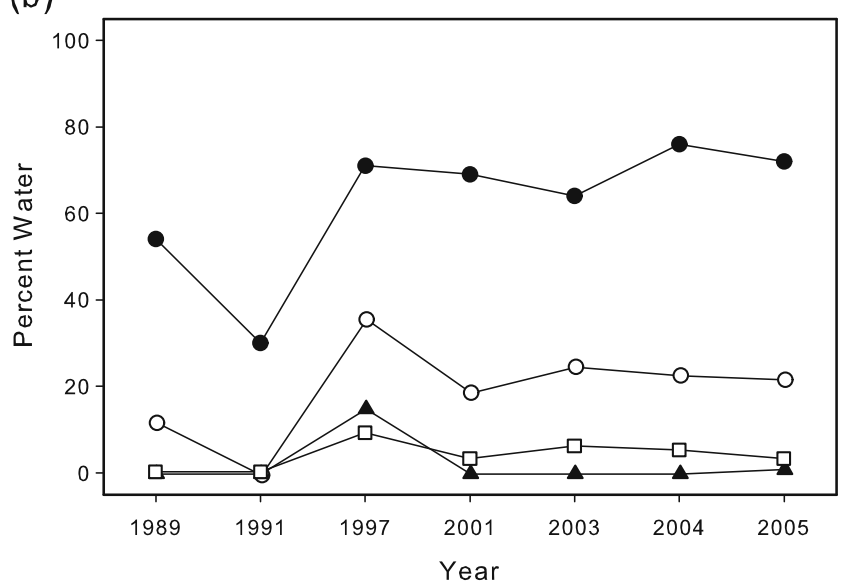

\begin{tabular}{|c|c|}
\hline- Recharge & $\neg-$ Flow-through \\
\hline -O- Open discharge & - Closed discharge \\
\hline
\end{tabular}

Fig. 4 Cluster centers calculated from a maximum water extent and $\mathbf{b}$ wetland delineation unit methods

\section{Field Validation}

To validate the results, we randomly selected 144 wetlands from National Wetlands Inventory (NWI) data to visit during the summer of 2008 (USFWS 2008). The selected wetlands were centrally located within a $400 \mathrm{~m}$ transect following roads that traversed the center of the study area in a north to south orientation. The hydrologic function of each wetland was assessed in the field by determining the topographic position of a wetland relative to nearby wetlands and identifying the species composition of its aquatic plant community.

Species composition of wetland plant communities is closely correlated with differences in wetland water chemistry (Stewart and Kantrud 1972) resulting primarily from species specific tolerances to dissolved salts (Kantrud et al. 1989). Therefore, plant species composition provided a surrogate measure of water chemistry and, when combined with topographic information, was used to reliably estimate hydrologic regime. Open and closed basins were discerned by identifying if surface outflow could occur. Those designated as closed basins had no outlet for surface water outflow, while open basins had water spilling or an area where water could potentially spill given high water conditions.

Of the 144 wetlands selected for validation, 87 were included in the final assessment (Table 3). A combination of factors limited the validity of certain samples $(n=22)$, including local relief obstructing the view of a wetland from the roadway and highly altered or indiscernible basin types. In addition, various small recharge and flow-through wetlands selected for validation from the NWI data (USFWS 2008; $\mathrm{n}=35$ ) did not correspond to a wetland delineation unit or a surface water polygon and therefore, could not be used for evaluation.

\section{Results}

\section{Hydrologic Function Classification}

Representative temporal patterns of remotely sensed surface water, as indicted by cluster centers from the unsupervised clustering (Fig. 4), were generally consistent with surface water dynamics exhibited by wetlands with known hydrologic functions at the CLSA (Fig. 3). At CLSA, all wetlands were dry in 1991 (Fig. 3). During deluge, closed discharge
Table 2 Calibration accuracy assessment of hydrologic function classifications $(\mathrm{R}=$ recharge; $\mathrm{FT}=$ flow-through; $\mathrm{OD}=$ open discharge; $\mathrm{CD}=$ closed discharge)

\begin{tabular}{lrrrrrr}
\hline \multirow{2}{*}{ Class } & \multicolumn{2}{l}{ Field survey data } & & Total & User's accuracy \\
\cline { 2 - 4 } & $\mathrm{R}$ & $\mathrm{FT}$ & $\mathrm{OD}$ & $\mathrm{CD}$ & & \\
\hline Cluster classification & 2 & 2 & 0 & 0 & 4 & $50 \%$ \\
$\mathrm{R}$ & 1 & 5 & 0 & 1 & 7 & $71 \%$ \\
FT & 0 & 1 & 7 & 0 & 8 & $88 \%$ \\
OD & 0 & 0 & 1 & 22 & 23 & $96 \%$ \\
CD & 3 & 8 & 8 & 23 & 42 & $86 \%$ \\
Total & $67 \%$ & $63 \%$ & $88 \%$ & $96 \%$ & - & \\
Producer's accuracy & & & & & \\
\hline
\end{tabular}


Table 3 Field assessment of remotely sensed hydrologic function classifications $(\mathrm{R}=$ recharge; FT = flow-through; $\mathrm{OD}=$ open discharge; $\mathrm{CD}=$ closed discharge)

\begin{tabular}{|c|c|c|c|c|c|c|}
\hline \multirow[t]{2}{*}{ Class } & \multicolumn{4}{|c|}{ Field survey data } & \multirow[t]{2}{*}{ Total } & \multirow[t]{2}{*}{ User's accuracy } \\
\hline & $\mathrm{R}$ & FT & OD & $\mathrm{CD}$ & & \\
\hline \multicolumn{7}{|c|}{ a. Classification accuracies of four hydrologic function classes } \\
\hline \multicolumn{7}{|l|}{ Cluster classification } \\
\hline $\mathrm{R}$ & 2 & 13 & 0 & 0 & 15 & $13 \%$ \\
\hline FT & 0 & 3 & 1 & 0 & 4 & $75 \%$ \\
\hline OD & 1 & 14 & 7 & 13 & 35 & $20 \%$ \\
\hline $\mathrm{CD}$ & 0 & 0 & 1 & 32 & 33 & $97 \%$ \\
\hline Total & 3 & 30 & 9 & 45 & 87 & - \\
\hline Producer's accuracy & $67 \%$ & $10 \%$ & $78 \%$ & $71 \%$ & - & $51 \%$ \\
\hline \multicolumn{7}{|c|}{ b. Classification accuracies of two hydrologic function classes } \\
\hline & $\mathrm{R} / \mathrm{FT}$ & & $\mathrm{OD} / \mathrm{C}$ & & & \\
\hline \multicolumn{7}{|l|}{ Cluster classification } \\
\hline $\mathrm{R} / \mathrm{FT}$ & 18 & & 1 & & 19 & $95 \%$ \\
\hline $\mathrm{OD} / \mathrm{CD}$ & 15 & & 53 & & 68 & $78 \%$ \\
\hline Total & 33 & & 54 & & 87 & - \\
\hline Producer's accuracy & $55 \%$ & & $98 \%$ & & - & $82 \%$ \\
\hline
\end{tabular}

wetlands at CLSA (Fig. 3), and those wetlands identified as closed discharge in the cluster analysis (Fig. 4), had consistently higher water levels. The 1997 spike in surface water was a key identifier of recharge wetlands (Figs. 3, 4). Known hydrologic functions in the flow-through and open discharge classes were both few in number, and inconsistent in their dynamics at CLSA (Fig. 3). The two classes from the unsupervised clustering with temporal patterns falling between closed discharge and recharge classes were labeled as open discharge and flow-through (Fig. 4). Note that while these classes exhibit similar dynamics as a percentage of maximum water extent (Fig 4a), there is greater separation between them when water extent is calculated as a percentage of wetland delineation units (Fig. 4b).

Results of the hydrologic function classification, as mapped by wetland delineation units across the Missouri Coteau, are illustrated in Figure 5. Hydrologic function predictions are generally consistent with expected landscape positions of the four functional wetland types. Closed discharge basins are located at topographic lows, both locally and regionally. Recharge wetlands are concentrated at local topographic highs. Flow-through and open discharge functional types tend to occupy intermediate positions between recharge and closed discharge wetlands.

\section{Accuracy Assessment}

Field validation revealed that we generally under-estimated the number of flow-through wetlands and over-estimated the number of open discharge wetlands (Table 3a). The classified data from the random survey included 15 recharge wetlands, but during field visits, 13 were determined to be flow-through wetlands. Twelve of these 13 misclassified flow-through wetlands had detectable water at only one date, resembling what we conceived prior to the cluster analysis to be recharge wetlands. Overprediction in the open discharge class was nearly evenly divided between wetlands that actually had flow-through or closed discharge functions (Table 3a), resulting in substantial declines in accuracy rates relative to wetlands used to calibrate the cluster analysis (Table 2). The reference sample for the recharge class included only three wetlands, a sample size too small for estimating the producer's accuracy for recharge wetlands with high confidence (Congalton 1991).

\section{Modified Hydrologic Function Classification}

A more general approach to classifying hydrologic function can be taken by combining; (1) recharge and flow-through wetlands, (2) open and closed discharge wetlands. When this is done, overall classification accuracy increases to $82 \%$ (Table $3 \mathrm{~b}$ ). The combination of recharge and flow-through represents a class with similar dynamics of a more temporary nature, equivalent to the temporary and seasonal classes in the Cowardin system (Cowardin and Golet 1995). Discharge wetlands with open and closed basins are more likely to contain water at multiple dates, equivalent to the semi-permanent class in the Cowardin system (Cowardin and Golet 1995). Nonetheless, over-prediction of open discharge wetlands as flow-through wetlands remains a source of error in this more general classification (Table 3b). 


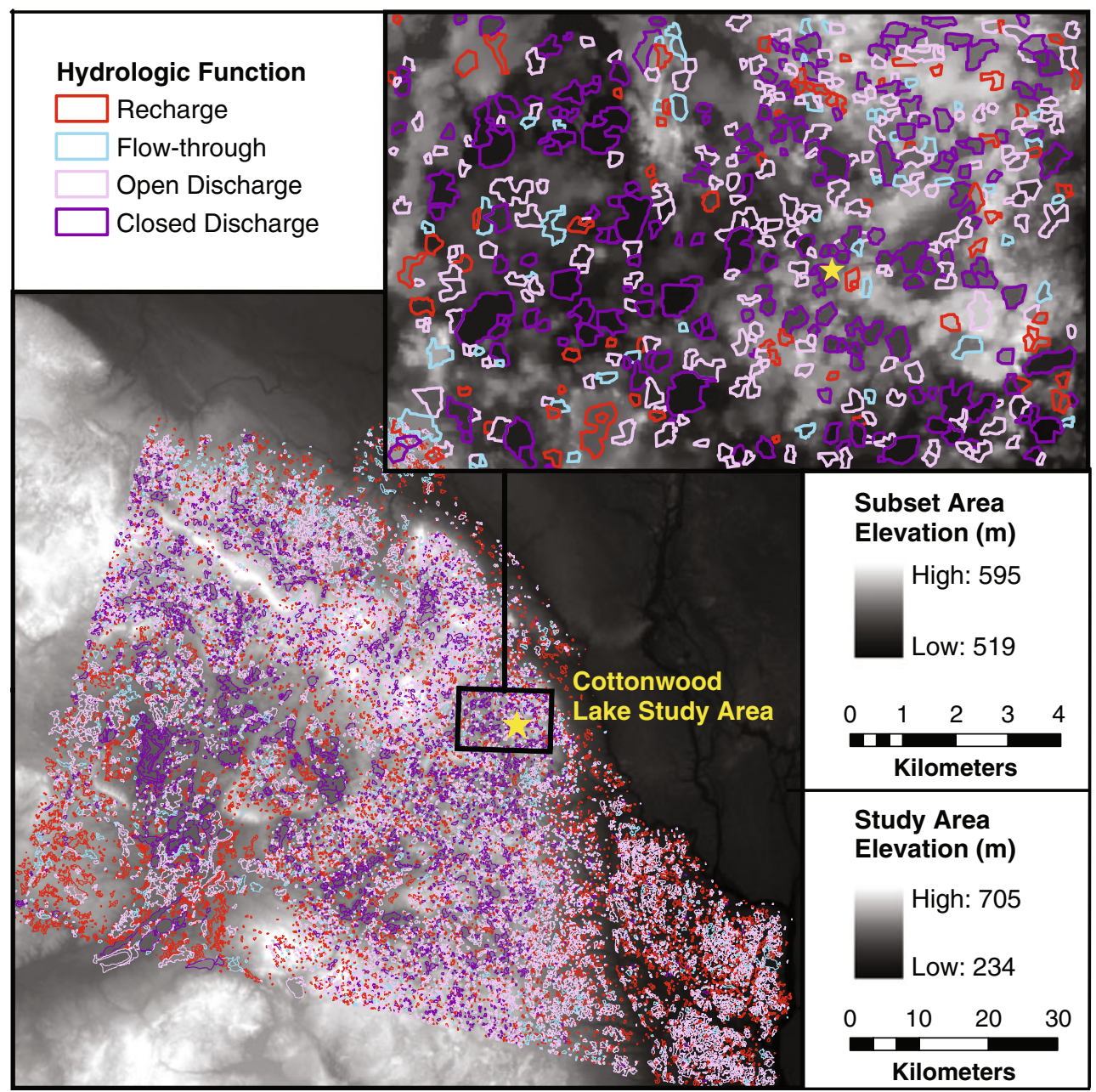

Fig. 5 Classification of hydrologic function in the Missouri Coteau and a subset area containing CLSA

\section{Discussion}

The results of our study suggest that cluster analysis is capable of grouping wetlands based on similarities in surface water dynamics and may generate improved results if several issues are addressed. A factor contributing to low accuracies was the inconsistent detection of small temporary recharge wetlands and their misclassifications as flowthrough wetlands that exhibited detectable water on a single date.

If high resolution data is available and feasible, we expect improved accuracies for smaller wetlands. The minimum size of surface water bodies that can be reliably detected using Landsat-based classifiers is approximately 0.7-1.0 ha (Federal Geographic Data Committee 1992; Lunetta and Balogh 1999; Zhang et al. 2009a, b). However, the average size of PPR wetlands is approximately 0.5 ha (van der Valk and Pederson 2003). Although existing remote sensing methods report reasonable water detection at approximately half-pixel $\left(225 \mathrm{~m}^{2}\right)$ water extents (Beeri and Phillips 2007), we expect surface water area calcu- lations for small wetlands with high percentages of mixed pixels, i.e., vegetation and water, to have underestimated water area. Accurately accounting for surface water in small wetlands may be improved by using a percent water calculation based on subpixel water estimates from Landsat (Sethre et al. 2005; Rover et al. 2010) rather than polygon area estimates. Our future goals include evaluating methods to reduce wetland omission, avoid confusion between classes, and assess the added benefits from incorporating higher resolution data, including SPOT 5, LiDAR, and RADARSAT-2.

Although wetland coalescence was addressed in this study, in some instances, the $30 \mathrm{~m}$ elevation data were not adequate for separating small recharge basins from large discharge basins. This resulted in misclassifications when the surface water dynamics from two or more adjacent wetlands with differing functions merged. The addition of higher resolution, more accurate elevation data that accounts for slight differences in slope may increase the number of small wetlands identified as unique units. Although a higher resolution DEM $(10 \mathrm{~m})$ was not 
available for the study area at the time of analysis, incorporating $10 \mathrm{~m}$ data, as well as LIDAR-derived digital elevation models, should be evaluated.

Adding a seasonal vegetation component to the classification may also provide additional information for the classification. Standing vegetation can reduce the extent of detectable water resulting in unreliable seasonal water extent changes. This effect would be observed in midseason data acquired after dense standing vegetation conceals open water. The Normalized Difference Vegetation Index (NDVI) or radar acquired during a growing season could be used to differentiate vegetation from water.

Following the same methods described in this paper, an overall study may be simplified and accuracies increased by simply limiting analysis to specific acquisition dates. Basing data selection on the surface water characteristics associated with each type of wetland and the temporal responses to precipitation events, separate classifications can be applied to multiple datasets. For instance, recharge wetlands tend to respond immediately to high precipitation events, especially spring snowmelt, and then quickly dry as water evaporates and infiltrates. An early spring acquisition, or several early spring acquisitions spanning multiple years, coupled with midseason acquisitions during the same years may provide dynamics that can be used to accurately identify recharge wetlands. In contrast, discharge wetlands usually continue to contain water during extremely dry periods, so acquiring data during extended periods of drought may reasonably capture wetlands receiving considerable amounts of groundwater discharge.

For studies that span larger geographic areas, grouping wetlands by similar climatic regions may also be necessary prior to developing classification algorithms. Local precipitation events have varying impacts on each wetland type. Considering significant climate gradients, including elevation, prior to cluster analysis may prevent unknowingly mixing wetlands subject to differing degrees of precipitation or snowmelt.

\section{Conclusions}

Although the results of our study were mixed, the method demonstrates that temporal surface water dynamics can be derived from Landsat imagery and used to quantify wetland dynamics. The method provides essential spatial hydrologic function information that does not currently exist to improve regional modeling. Calibrating the classes is challenging and requires a representative sample of wetland types across the area of interest.

We found this method to be capable of classifying closed discharge wetlands across a large area, although other wetland functional types were problematic, and the results may vary for other areas of the PPR. The classification of hydrologic functional types is limited by the ability to detect water on more than a single date and to separate wetlands during high water events when neighboring wetlands tend to coalesce. Several suggested improvements may increase overall accuracy and the reliability of this method for separating wetland dynamics by functional types.

We designed this approach to map hydrologic function for wetlands located in one area of the Missouri Coteau, but object extraction and clustering methods may be applicable to wetlands, lakes, or rivers in other areas of the PPR and with modifications, in other regions. In addition, this methodological approach could be applied to other temporally dynamic objects. In the future, as we refine our ability to group wetlands based on similar responses to precipitation and temperature, we will have an opportunity to predict how surface water might respond to a range of future climate scenarios and provide an assessment of the contributions to ecosystem services that PPR wetlands provide.

Acknowledgments This collaborative work was supported by the U.S. Geological Survey (USGS) Integrated Landscape Monitoring initiative. Funding was provided by USGS Central Region Integrated Studies Program (CRISP), Carbon Cycle Research (Land Remote Sensing), Climate Effects Network (Global Change Office), and USGS Earth Resources Observation and Science Center over-guide. We thank John Melack and Gabriel Senay for their reviews and Lei Ji for assisting with graphics. Use of brand names in this manuscript does not constitute nor imply endorsement by the U.S. Government.

\section{References}

Baker C, Lawrence RL, Montagne C, Patten D (2007) Change detection of wetland ecosystems using Landsat imagery and change vector analysis. Wetlands 27:610-619

Beeri O, Phillips RL (2007) Tracking palustrine water seasonal and annual variability in agricultural wetland landscapes using Landsat from 1997 to 2005. Global Change Biology 13:897-912

Congalton RG (1991) A review of assessing the accuracy of classifications of remotely sensed data. Remote Sensing of Environment 37:35-46

Cowardin LM, Golet FC (1995) US Fish and Wildlife Service 1979 Wetland classification: a review. Plant Ecology 118:139-152

ESRI (2006) ArcGIS 9.2. ESRI, Inc., California

Euliss NH Jr, LaBaugh JW, Fredrickson LH, Mushet DM, Laubhan MK, Swanson GA, Winter TC, Rosenberry DO, Nelson RD (2004) The wetland continuum: a conceptual framework for interpreting biological studies. Wetlands 24:448-458

Federal Geographic Data Committee (1992) Application of satellite data for mapping and monitoring wetlands: Fact finding report. Wetlands Subcommittee, Reston

High Plains Regional Climate Center (2005) Historical climate data summaries, Woodworth 3 E, North Dakota (329575), 6/ 1/1951 to $4 / 30 / 2005$. Available via http://www.hprcc.unl.edu/data/ historical/. Accessed 26 August 2010 
Henderson FM, Lewis AJ (2008) Radar detection of wetland ecosystems: a review. International Journal of Remote Sensing 29:5809-5835

Jenson SK (1991) Applications of hydrologic information automatically extracted from digital elevation models. Hydrological Processes 5:31-44

Jenson SK, Domingue O (1988) Extracting topographic structure from digital elevation data for geographic information system analysis. Photogrammetric Engineering and Remote Sensing 54:1593-1600

Johnson WC, Boettcher SE, Poiani KA, Guntenspergen GR (2004) Influence of weather extremes on the water levels of glaciated prairie wetlands. Wetlands 24:385-398

Jones BM, Arp CD, Hinkel KM, Beck RA, Schmutz JA, Winston B (2009) Arctic lake physical processes and regimes with implications for winter water availability and management in the National Petroleum Reserve Alaska. Environmental Management 43:1071-1084

Kantrud HA, Krapu GL, Swanson GA (1989) Prairie basin wetlands of the Dakotas: A community profile. Biological Report 85 (7.28). US Fish and Wildlife Service, Washington

Kaufman L, Rousseeuw PJ (2005) Finding groups in data: An introduction to cluster analysis, 2nd edn. Wiley, Hoboken

Koshel P, McAllister K (2008) Transitioning to sustainability through research and development on ecosystem services and biofuels: Workshop summary. National Research Council, The National Academies Press, Washington, DC

LaBaugh JW (1989) Chemical characteristics of water in northern prairie wetlands. In: van der Valk AG (ed) Northern prairie wetlands. Iowa State University Press, Ames, pp 56-90

LaBaugh JW, Winter TC, Rosenberry DO (1998) Hydrologic function of prairie wetlands. Great Plains Research 8:17-37

LaBaugh JW, Winter TC, Swanson GA, Rosenberry DO, Nelson RD, Euliss NH Jr (1996) Changes in atmospheric circulation patterns affect midcontinent wetlands sensitive to climate. Limnology and Oceanography 41:864-870

Leahy MG, Jollineau MY, Howarth PJ, Gillespie AR (2005) The use of Landsat data for investigating the long-term trends in wetland change at Long Point, Ontario. Canadian Journal of Remote Sensing 31:240-254

Lunetta RS, Balogh ME (1999) Application of multi-temporal Landsat 5 TM imagery for wetland identification. Photogrammetric Engineering and Remote Sensing 65:1303-1310

Melack JM (2004) Tropical freshwater wetlands. In: Ustin SL (ed) Remote sensing for natural resource management and environmental monitoring. Wiley, Hoboken, pp 319-343

Mertes LAK, Dekker AG, Brakenridge GR, Birkett CM, Létourneau G (2004) Rivers and lakes. In: Ustin SL (ed) Remote sensing for natural resource management and environmental monitoring. Wiley, Hoboken, pp 345-400

Ozesmi SL, Bauer ME (2002) Satellite remote sensing of wetlands. Wetlands Ecology and Management 10:381-402

Rosenberry DO (2003) Climate of the cottonwood lake area. In: Winter TC (ed) Hydrological, chemical, and biological character- istics of a prairie pothole wetland complex under highly variable climate conditions - The Cottonwood Lake Area, East-central North Dakota, U. S. Geological Survey Professional Paper 1675, pp 25-34

Rover JA, Wylie BK, Ji L (2010) A self-trained classification technique for producing 30-m percent-water maps from Landsat data. International Journal of Remote Sensing 31:2197-2203

Sethre PR, Rundquist BC, Todhunter PE (2005) Remote detection of Prairie Pothole ponds in the Devils Lake basin, North Dakota. GIScience Remote Sensing 42:277-296

Stewart RE, Kantrud HA (1972) Vegetation of Prairie Potholes, North Dakota, in relation to quality of water and other environmental factors. U. S. Geological Survey Professional Paper 585-D. United States Government Printing Office, Washington

Swanson GA, Winter TC, Adomaitis VA, LaBaugh JW (1988) Chemical characteristics of prairie lakes in south-central North Dakota - their potential for influencing use by fish and wildlife. Technical Report 18. US Fish \& Wildlife Service, Washington

Swanson GA, Euliss NH Jr, Hanson BA, Mushet DM (2003) Dynamics of a prairie wetland complex: implications for wetland management. In: Winter TC (ed) Hydrological, chemical, and biological characteristics of a prairie pothole wetland complex under highly variable climate conditions - The Cottonwood Lake Area, East-central North Dakota, U. S. Geological Survey Professional Paper 1675, pp 55-94

US Fish and Wildlife Service (2008) National Wetlands Inventory. Available via http://www.fws.gov/wetlands/data/DataDownload. html. Accessed 26 May 2010

US Geological Survey (2001) Multi-Resolution Land Characteristics (MRLC), National Land Cover Dataset (NLCD). Available via http://www.mrlc.gov. Accessed 26 May 2010

US Geological Survey (2006) National Elevation Data, Digital Elevation Models (DEM). Earth Resources Observation and Science (EROS) Center. Available via http://ned.usgs.gov. Accessed 26 May 2010

van der Valk AG, Pederson RL (2003) The SWANCC decision and its implications for Prairie Potholes. Wetlands 23:590-596

van der Valk AG (2005) Water-level fluctuations in North American prairie wetlands. Hydrobiologia 539:171-188

Winter TC, Rosenberry DO (1998) Hydrology of Prairie Pothole wetlands during drought to deluge: a 17-year study of the Cottonwood Lake wetland complex in North Dakota in the perspective of longer term measured and proxy hydrological records. Climatic Change 40:189-209

Work EA Jr, Gilmer DS (1976) Utilization of satellite data for inventorying prairie ponds and lakes. Photogrammetric Engineering and Remote Sensing 42:685-694

Zhang B, Schwartz FW, Tong D (2009a) Landsat sub-pixel analysis in mapping impact of climatic variability on Prairie Pothole changes. Transactions in GIS 13:179-195

Zhang B, Schwartz FW, Liu G (2009b) Systematics in the size structure of prairie pothole lakes through drought and deluge. Water Resources Research 45:W0442 